DOI: $10.26418 /$ positron.v11i2.49699

\title{
Biosynthesis of Zinc Oxide Powder Using Sandoricum koetjape Peel Extract at Various Annealing Temperature
}

\author{
Ari Sulistyo Rini*, Nurul Hidayanti, Yolanda Rati \\ aJurusan Fisika FMIPA, Universitas Riau, Kampus Bina Widya, JL. HR. Soebrantas, KM 12,5, Tampan, \\ Pekanbaru 28293, Indonesia \\ *Email : ari.sulistyo@lecturer.unri.ac.id \\ (Diterima 30 September 2021; Disetujui 1 Desember 2021; Dipublikasikan 29 Desember2021)
}

\begin{abstract}
Zinc oxide (ZnO) synthesized with natural reductants has attracted the attention of researchers because it is environmentally friendly and non-toxic. In this study, $\mathrm{ZnO}$ was prepared using Sandoricum koetjape $(S$. koetjape) peel extract. An aqueous extract of $S$. koetjape peel was used as biological reduction agent for the synthesis of $\mathrm{ZnO}$ from zinc nitrate hexahydrate. The $\mathrm{ZnO}$ powder obtained was annealed at different temperatures i.e, $300^{\circ} \mathrm{C}, 400^{\circ} \mathrm{C}$, and $500^{\circ} \mathrm{C}$ for 1 hour. Structural, morphological, optical properties, and functional groups of samples were analyzed using X-Ray Diffraction, Scanning Electron Microscopy, UVVis Spectroscopy, and Fourier Transform Infrared Spectroscopy, respectively. The X-ray diffraction pattern shows that pure hexagonal wurtzite structure of $\mathrm{ZnO}$ particles can be achieved after annealing. The crystal size has also increased with increasing annealing temperature. SEM photo demonstrates the transformation of $\mathrm{ZnO}$ particle from spherical to microflower due to annealing. The widest absorption peaks in the UV-Vis spectrum was occurred after annealing at $500^{\circ} \mathrm{C}$. The bandgap energy of $\mathrm{ZnO}$ increases after annealing from $3.08 \mathrm{eV}$ to $3.20 \mathrm{eV}$. The FT-IR analysis confirms $\mathrm{O}-\mathrm{H}$ functional group from extract has been decomposed due to the annealing process. Based on this study, biosynthesized ZnO using Sandoricum koetjape peel extract requires annealing process to improve the purity, enhance the light absorbance and change the microstructure of $\mathrm{ZnO}$.
\end{abstract}

Keywords: ZnO, Sandoricum koetjape, reductant, annealing, spherical

\section{Introduction}

Zinc oxide (ZnO) is a metal oxide semiconductor that has been widely applied in materials science due to its unique physical, chemical, and biological properties such as wide light absorbance, chemically stable and nontoxic[1]. ZnO has been applied in the field of catalysis for wastewater treatment, cosmetics and antimicrobial additives[2]. However, the synthesis method to produce $\mathrm{ZnO}$ still involves many toxic chemicals which pose a threat to human health and the environment[3]. The biosynthesis method has received considerable attention because it is cheap, simple, and does not require dangerous chemicals.

Biosynthesis is a method of material synthesis by utilizing media from biological materials such as microorganisms and plants. When compared to biosynthesis using microorganisms, biosynthesis using plant extracts is simpler. This is because the biosynthetic method with plant extracts does not need to prepare microorganism media or cell culture, which is a fairly complicated process [4]. The plant extracts were used as biostabilizer in the synthesis of $\mathrm{ZnO}$. This role is related to the antioxidant activity of the secondary metabolites contained in plants such as flavonoids, polyphenols, and alkaloids. These compounds can be obtained from various plant parts such as leaves, stems, roots, shoots, flowers, bark, and seeds[5]. Various plant extracts have been widely used in the synthesis of $\mathrm{ZnO}$, such as Aloe vera, Camellian sinensis, and Borassur flabellifer leaves[6]. The S. koetjape is a traditional plant that is originated from Southeast Asia including Indonesia. The main by-product of $S$. koetjape, the fruit peel, is high in antioxidants which contains alkaloids, flavonoids, tannins, saponins, glycosides, anthraquinone, glycosides and steroids[7]. Therefore, the extract of $S$. koetjape peel is believed to be used as a stabilizer in the synthesis of $\mathrm{ZnO}$. However, biosynthesis of $\mathrm{ZnO}$ based on $S$. koetjape peel extract has not been investigated.

Synthetics condition such as precursor concentration, $\mathrm{pH}$ level, plants extract used and annealing temperature may result different physical and chemical properties of the material. In this study, ZnO was synthesized using the fruit peel extract of $S$. koetjape at various annealing 
temperature. Structural properties, surface morphology, optical properties and functional groups of ZnO samples synthesized with various annealing temperature were analyzed.

\section{Material and Methods}

\subsection{Materials}

The materials used in this study were the peel of $S$. koetjape fruit as a stabilizing agent obtained from traditional markets, Pekanbaru City, and zinc nitrate hexahydrate $\left(\mathrm{Zn}\left(\mathrm{NO}_{3}\right)_{2} \cdot 6 \mathrm{H}_{2} \mathrm{O}\right)$ as a source of Zn purchased from Smart Lab. Sodium hydroxide $(\mathrm{NaOH})$ is purchased from MERCK as catalyst and demineralized-water (aqua DM) was used as the synthesis medium.

\subsection{Preparation of $S$. koetjape Peel Extract}

The peel of $S$. koetjape was cut into small pieces using a sterile knife, then cleaned with water and dried under the sun until the mass was constant. Dried S. koetjape peel was grinded using a blender. $20 \mathrm{~g} / \mathrm{L}$ of $S$. koetjape extract was prepared by dissolving 10 grams of peel powder into $500 \mathrm{ml}$ of aqua DM. Extracts solution were heated at $80^{\circ} \mathrm{C}$ for 10 minutes to increase polyphenol content[8]. The extract was then filtered using Whatman filter paper No. 1 and stored at $4^{\circ} \mathrm{C}$ for further use.

\subsection{Biosynthesis of Zinc Oxide}

$160 \mathrm{ml}$ of aqueous Zinc Nitrate Hexahydrate $50 \mathrm{mM}$ was added into $40 \mathrm{ml}$ of $S$. koetjape peel extract. $\mathrm{NaOH}$ was then dripped into the solution to achieve $\mathrm{pH}$ of 12 . The solution was then heated at $60^{\circ} \mathrm{C}$ for 2 hours. Afterward, the solution was allowed to settle overnight. The precipitate was separated using electronic centrifuge Oregon at $4000 \mathrm{rpm}$ for $10 \mathrm{~min}$ and washed by Aqua DM several times. The obtained $\mathrm{ZnO}$ powder was dried at $60^{\circ} \mathrm{C}$ for $24 \mathrm{~h}$. The $\mathrm{ZnO}$ powder was then annealed at different temperatures i.e, $300^{\circ} \mathrm{C}$, $400^{\circ} \mathrm{C}$, and $500^{\circ} \mathrm{C}$ for 1 hour. The schematic of the $\mathrm{ZnO}$ synthesis is shown in Figure 1.

\subsection{Characterization of Zinc Oxide}

The optical properties, structure, morphology and functional groups of $\mathrm{ZnO}$ samples were analyzed based on the characterizations using Ultaviolet-Visible spectrophotometer (SHIMATSU) in the range 200-800 $\mathrm{nm}, \mathrm{X}$-Ray Diffractometer (Rigaku MiniFlex) with $\mathrm{CuK} \alpha$ radiation $(\lambda=0.154$ nm), Scanning Electron Microscopy (Hitachi Flexsem 1000), and a Fourier Transform Infared

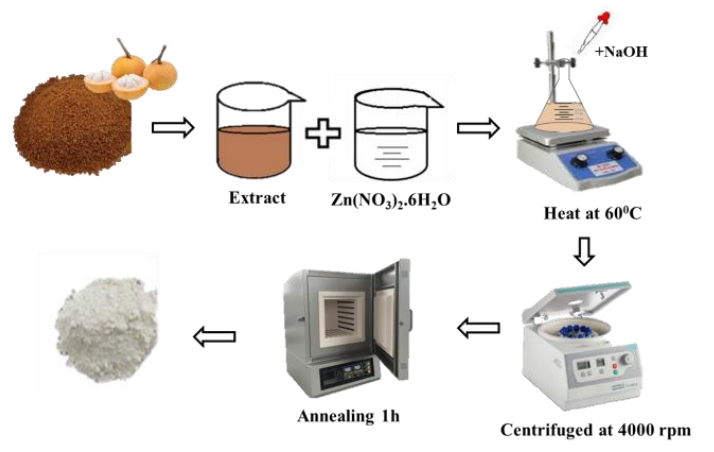

Figure 1. Schematic synthesis of $\mathrm{ZnO}$

spectrophotometer (Simadzu IRPrestige-21), respectively. The particle diameter of the $\mathrm{ZnO}$ sample was measured using the Image J application by adjusting the scale contained in the SEM image.

\section{Result and Dicussion \\ 3.1 Structural Properties}

The X-ray diffraction spectrum of the asprepared (without annealed) and annealed $\mathrm{ZnO}$ biosynthetic sample is shown in Figure 2. The diffraction pattern of all $\mathrm{ZnO}$ samples exhibits the crystal structure of hexagonal wurtzite $\mathrm{ZnO}$ with crystal planes (100), (002), (101), (012), and (110). The peaks of the hkl planes mentioned are the same as the results of previous studies by Sari et al[9].

The ZnO sample with an annealing temperature of $500^{\circ} \mathrm{C}$ has the highest intensity of the strongest peak which imply its highest crystallity properties. The intensity of the diffraction peak increases as the annealing temperature increases[10]. This indicates an increase in the crystallinity of the sample which is associated with the high thermal energy supplied during the annealing process and promote the

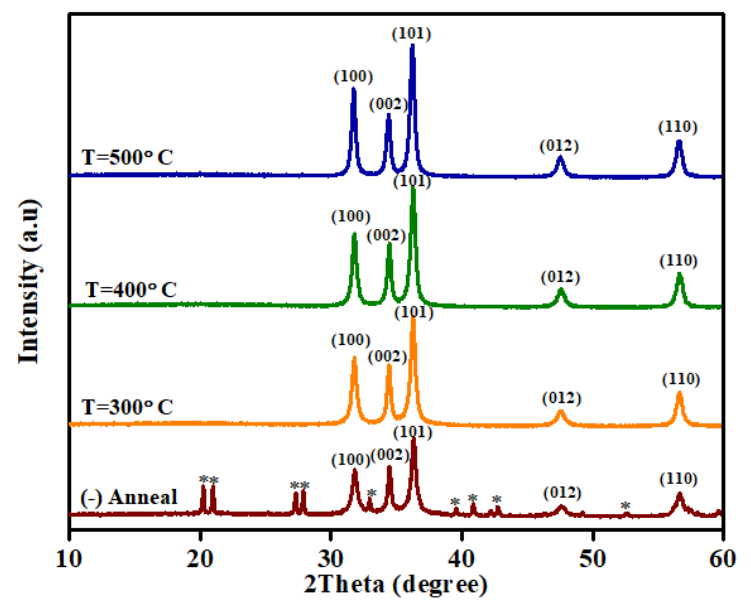

Figure 2. The diffraction spectrum of the $\mathrm{ZnO}$ sample without (-) and with annealing 

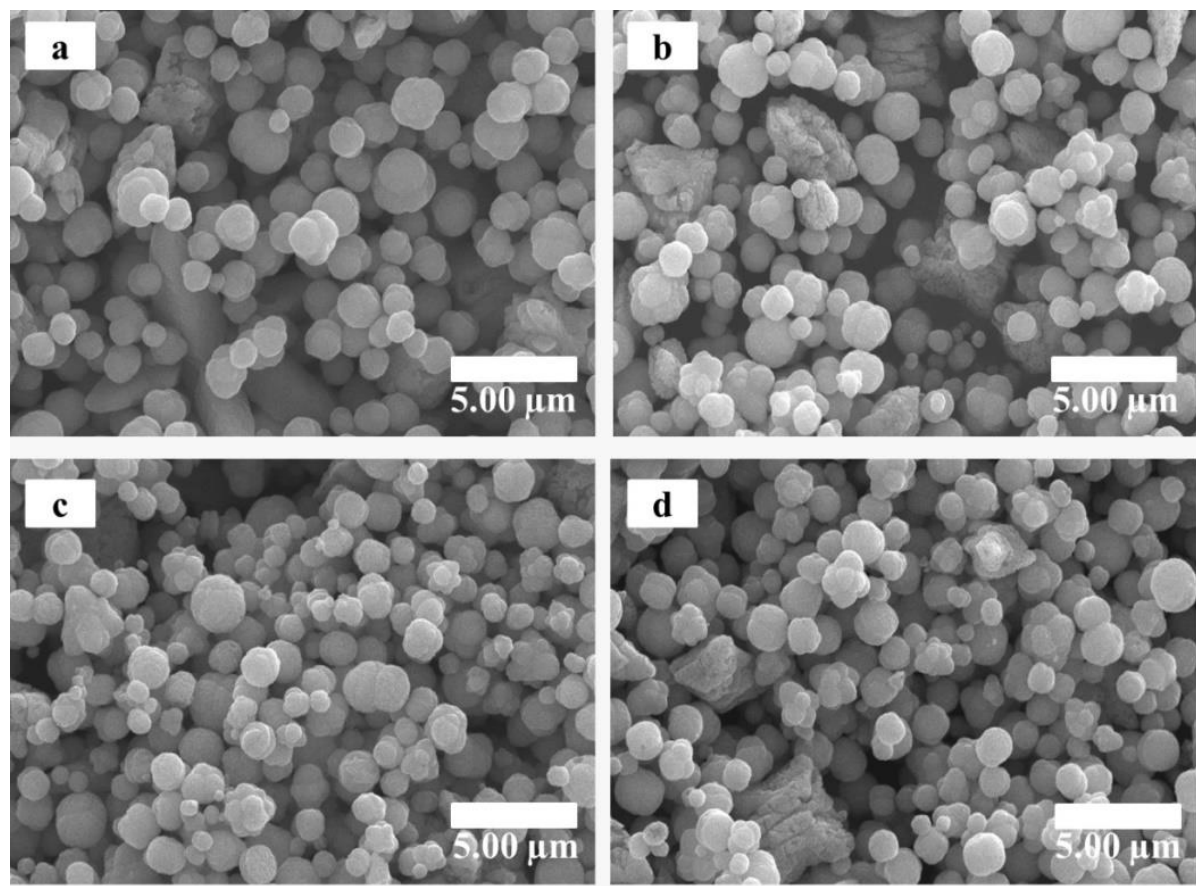

Figure 3. Surface morphology of $\mathrm{ZnO}$ samples (a) Without Annealing, (b) Annealing $\mathrm{T}=300^{\circ} \mathrm{C}$, (c) $\mathrm{T}=400^{\circ} \mathrm{C},(\mathrm{d}) \mathrm{T}=500^{\circ} \mathrm{C}$ at $10,000 \mathrm{X}$ magnification

migration of atoms to the correct lattice position. As a result, crystal defects are reduced and cause recrystallization in the $\mathrm{ZnO}$ lattice[11].

In the $\mathrm{ZnO}$ sample without annealing, there are another phase indicated by the presence of small peaks $(*)$. This is most probably be due to the influence of the $S$. koetjape peel extract which still existed in the sample. The annealing process can be considered to improve the crystallinity level as well as the purity of the sample. The FWHM value of each sample were obtained by fitting the Gaussian equation and the crystal size was calculated using the Scherrer equation as presented in Table 1.

Table 1. FWHM value and crystal size of $\mathrm{ZnO}$ sample at plane (101)

\begin{tabular}{|c|c|c|c|}
\hline $\begin{array}{c}\text { Sample } \\
\text { ZnO }\end{array}$ & $\mathbf{2 \theta} \mathbf{(}^{\mathbf{0}} \mathbf{)}$ & $\begin{array}{c}\text { FWHM } \\
\mathbf{(}^{\mathbf{0}}\end{array}$ & $\begin{array}{c}\text { Crystallin } \\
\text { e Size } \\
\text { (nm) }\end{array}$ \\
\hline (-) Anneal & 36,313 & 0,444 & 17,762 \\
$300^{\circ} \mathrm{C}$ & 36,263 & 0,458 & 17,221 \\
$400^{\circ} \mathrm{C}$ & 36,269 & 0,446 & 17,684 \\
$500^{\circ} \mathrm{C}$ & 36,217 & 0,428 & 18,431 \\
\hline
\end{tabular}

The $\mathrm{ZnO}$ sample with an annealing temperature of $500^{\circ} \mathrm{C}$ had the largest crystal size compared to other samples. This is because the increasing annealing temperature causes the crystal size to enlarge which is indicated by narrowing the FWHM value. This behavior could be attributed to the strain effect or crystallite size increasing that could be contribute to XRD peak broadening[11].

\subsection{Surface Morphology}

The surface morphology of the $\mathrm{ZnO}$ sample synthesis using $S$. koetjape peel extract is shown in Figure 3.

The particle morphology of the $\mathrm{ZnO}$ sample is mostly in spherical shape. Particle growth in the annealed $\mathrm{ZnO}$ sample is denser than the $\mathrm{ZnO}$ sample without annealing. The shape of the annealed sample particles in Figure 3 (b-d) is almost not uniform as evidenced by the presence of flower-like particles. These results are similar to the research conducted by Kabir et al[12].

Table 2. ZnO sample particle sizes

\begin{tabular}{|c|c|}
\hline Sample ZnO & Diameter (nm) \\
\hline$(-)$ Anneal & $840 \pm 215.7$ \\
$300^{\circ} \mathrm{C}$ & $839.1 \pm 275.2$ \\
$400^{\circ} \mathrm{C}$ & $794.7 \pm 206.1$ \\
$500^{\circ} \mathrm{C}$ & $750.4 \pm 193.4$ \\
\hline
\end{tabular}

The size of the $\mathrm{ZnO}$ particle diameter is presented in Table 2. Each $\mathrm{ZnO}$ sample has only a slight difference in diameter size. Increasing the annealing temperature causes the particle diameter to decrease. The particle size determined based on the XRD results is inconsistent with the results of the SEM analysis. This inconsistency might be due to morphological changing from 
spherical to micro-flower shape that occurred during annealing[12].

\subsection{Optical Properties}

The UV-Vis absorbance spectrum of the synthesized $\mathrm{ZnO}$ sample without annealing and after annealing are shown in Figure 4.

Strong absorption peaks of all samples occur at wavelengths around $300-380 \mathrm{~nm}$. The maximum absorption values for each sample are, 0.46 a.u, 1.34 a.u, 0.90 a.u and 1.26 a.u representing samples without annealing, annealed at temperatures of $300^{\circ} \mathrm{C}, 400^{\circ} \mathrm{C}$ and 500 , respectively. The $\mathrm{ZnO}$ sample annealed at $500^{\circ} \mathrm{C}$ have a widest absorption peaks. The spectrum obtained is in accordance with the optical properties of $\mathrm{ZnO}$ which is generally in the ultraviolet area[13].

The $\mathrm{ZnO}$ bandgap energy is obtained from the intersection of the curve $(\alpha h v)^{2}$ versus hv (Figure 5). The band gap energy decreases as the annealing temperature increases. For annealed samples, increasing annealing temperature is followed by a decrease in band gap energy from 3.20 to $3.11 \mathrm{eV}$ which in line with crystallinity improvement as described in the XRD analysis[14].

\subsection{Functional Group}

The FTIR spectrum of the $\mathrm{ZnO}$ sample is shown in Figure 6. Infrared peak absorption for the unannealed and annealed $\mathrm{ZnO}$ samples appeared at wavenumbers $443.4 \mathrm{~cm}^{-1}$ and 413.6 $\mathrm{cm}^{-1}$ are corresponded to $\mathrm{Zn}-\mathrm{O}$ bond with a hexagonal wurtzite phase[5]. These results are in accordance with the crystal structure analysis using XRD. The annealed $\mathrm{ZnO}$ sample has higher Zn-O peak absorption compare to unannealed

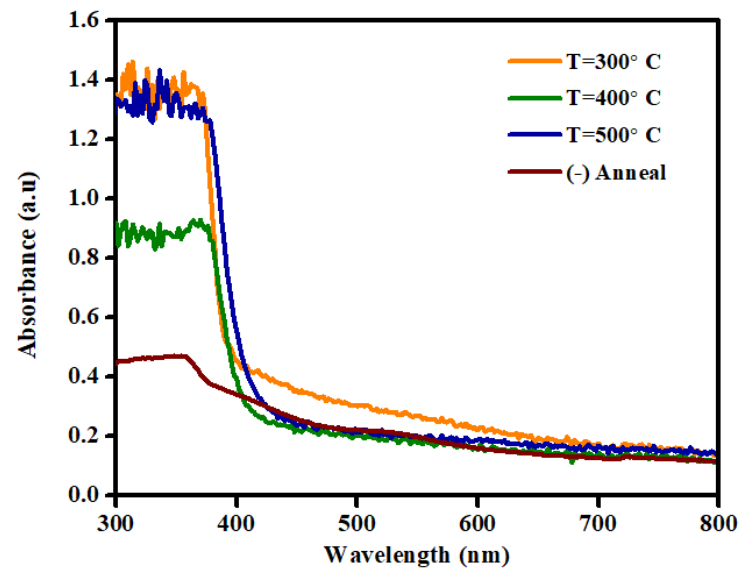

Figure 4. The absorbance spectrum UV-Vis of the sample $\mathrm{ZnO}$
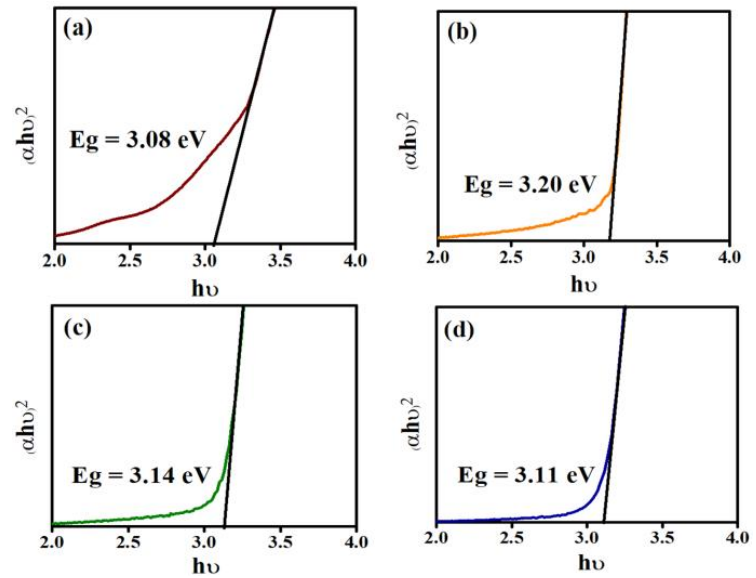

Figure 5. Energy gap of $\mathrm{ZnO}$ samples (a) Without Annealing, (b) Annealing $\mathrm{T}=300^{\circ} \mathrm{C}$, (c) $\mathrm{T}=400^{\circ} \mathrm{C}$, (d) $\mathrm{T}=500^{\circ} \mathrm{C}$

sample. It suggests the improvement of $\mathrm{ZnO}$ crystalline structure as indicated by the XRD results[15]. The FT-IR spectrum of the green synthesized $\mathrm{ZnO}$ NPs also showed phytochemical adsorption on the surface of the nanostructure as stabilizing and capping agents, which strongly protect the nanoparticles from decomposition, deformation, and coagulation processes [16] .

The $\mathrm{ZnO}$ sample without annealing has a broad peak at $3237.6 \mathrm{~cm}^{-1}$ due to the absorption of the $\mathrm{O}-\mathrm{H}$ functional group. This bond originates from phenol molecules in the $S$. koetjape peel extract which still attached on $\mathrm{ZnO}[17,18]$. In the $1538.5 \mathrm{~cm}^{-1}$ area, the $\mathrm{ZnO}$ sample without annealing had a $\mathrm{C}=\mathrm{C}$ aromatic bond vibration. The absorption peaks at wavenumber $\sim 1290 \mathrm{~cm}^{-1}$ for both samples indicate $\mathrm{C}-\mathrm{N}$ functional groups of amines and amides. In addition, there are also aromatic bonds originating from the $\mathrm{C}-\mathrm{H}$ functional group in the wavenumber of $844.4 \mathrm{~cm}^{-1}$ and $837.8 \mathrm{~cm}^{-1}$ at samples without annealing and

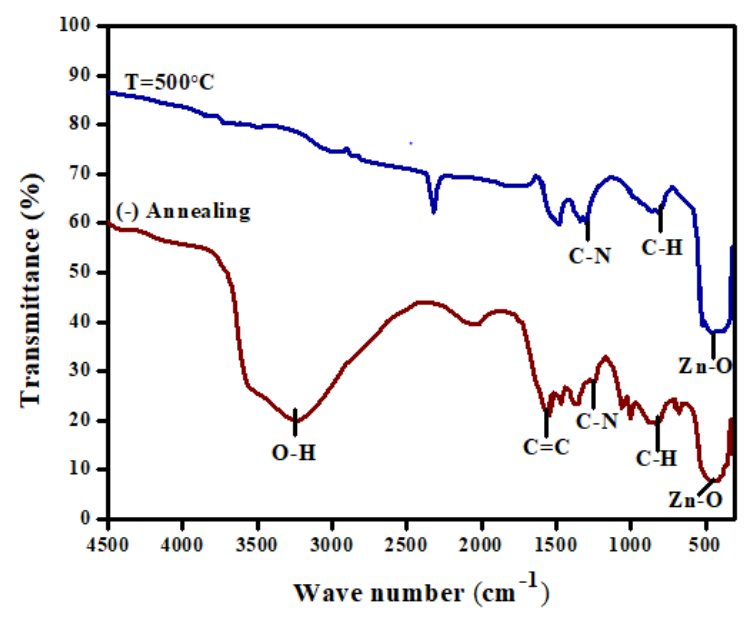

Figure 6. FTIR spectrum of the sample $\mathrm{ZnO}$ 
annealed samples, respectively. This functional group was also obtained in Moringa oleifera extract[18] and Camellia Sinensis extract[6]. The transformation of $\mathrm{Zn}\left(\mathrm{NO}_{3}\right)_{2} .6 \mathrm{H}_{2} \mathrm{O}$ salt to $\mathrm{ZnO}$ nanoparticles are stabilized by $\mathrm{O}-\mathrm{H}$ functional group from alkaloids, flavonoid, tannin and saponin compounds of $S$. koetjape extract, as also proposed by Martinise et al[18] in $\mathrm{ZnO}$ formation with Moringa oleifera extract. However, in the sample with an annealing temperature of $500^{\circ} \mathrm{C}, \mathrm{O}$ $\mathrm{H}$ functional group bonds were not found. This is because the $\mathrm{O}-\mathrm{H}$ functional group has been decomposed due to the annealing process $[11,18]$.

\section{Conclusion}

$\mathrm{ZnO}$ biosynthesis using $S$. koetjape peel extract has been carried out by varying the annealing temperature. UV-Vis absorption of $\mathrm{ZnO} 500{ }^{\circ} \mathrm{C}$ sample shows a widest absorbance at wavelength range of 350-380 nm with a bandgap energy of 3.11 eV. The XRD pattern shows that $\mathrm{ZnO}$ without annealing still contains impurities, while the annealed $\mathrm{ZnO}$ is pure a hexagonal wurtzite structure. SEM image indicates few shape transformation from spherical to micro-flower due to annealing. The FTIR spectrum shows the involvement of $\mathrm{O}-\mathrm{H}$ functional group derived from the peel extract of $S$. koetjape in the process of synthesizing $\mathrm{ZnO}$ which acts as a stabilizer and chelating agent. The FTIR spectrum shows the involvement of $\mathrm{O}-\mathrm{H}$ functional group derived from the peel extract of S. koetjape in the process of synthesizing $\mathrm{ZnO}$ which acts as a stabilizer and chelating agent. An annealing step is required for the synthesis of pure $\mathrm{ZnO}$ utilizing Sandoricum koetjape peel extract to increase light absorbance, and to modify the microstructure of $\mathrm{ZnO}$.

\section{Acknowledgement}

We thank to Lembaga Penelitian dan Pengabdian Masyarakat, University of Riau for facilitating this research.

\section{References}

[1] Lee,K. M., Lai, C. W., Ngai, K. S., and Juan, J. C., Recent developments of zinc oxide based photocatalyst in water treatment technology: A review, Water Res., 88, pp. 428-448, 2016.

[2] Ruszkiewicz, J. A., Pinkas, A., Ferrer, B., Peres, T. V., Tsatsakis, A., and Aschner, M., Neurotoxic effect of active ingredients in sunscreen products, a contemporary review,
Toxicol. Reports, 4, pp. 245-259, 2017.

[3] Zikalala, N., Matshetshe, K., Parani, S., and Oluwafemi, O. S., Biosynthesis protocols for colloidal metal oxide nanoparticles, NanoStructures and Nano-Objects, 16(9), pp. 288299, 2018.

[4] Rupiasih, N., Aher, A., Gosavi, S., and Vidyasagar, P. B., Green synthesis of silver nanoparticles using latex extract of Thevetia peruviana: A novel approach towards poisonous plant utilization, J. Phys. Conf. Ser., 423(1), pp. 1-8, 2013.

[5] Fadillah, R., Rati, Y., Dewi, R., Farma, R., and Rini, A. S., Optical and structural studies on bio-synthesized $\mathrm{ZnO}$ using Citrullus lanatus peel extract, J. Phys. Conf. Ser., 1816(1), pp.17, 2021.

[6] Senthilkumar, S. R. and Sivakumar, T., Green tea (Camellia sinensis) mediated synthesis of zinc oxide ( $\mathrm{ZnO}$ ) nanoparticles and studies on their antimicrobial activities, Int. J. Pharm. Pharm. Sci., 6(6), pp. 461-465, 2014.

[7] Wirata, I. N., Agung, A. A. G., Arini, N. W., and Nuratni, N. K., Sentul Fruit (Sandoricum koetjape) Peel as Anti-Inflammation for Gingivitis after Scaling, J. Heal. Med. Sci., 4(4), pp. 27-36, 2021.

[8] Rini, A. S. Adzani, H. Husain, T. S. L. Deraf, M. P. Rati, Y. and Hamzah, Y. Structural and morphological studies of silver nanoparticles prepared using citrullus lanatus rind extract, AIP Conf. Proc., 2320, pp. 1-6, 2021.

[9] Sari, R. N., Saridewi, N., and Shofwatunnisa, S., Biosynthesis and Characterization of $\mathrm{ZnO}$ Nanoparticles with Extract of Green Seaweed Caulerpa sp., J. Perikan. Univ. Gadjah Mada, 19(1), pp. 17-28, 2017.

[10] Sheik Mydeen, S., Raj Kumar, R., Kottaisamy, M., and Vasantha, V. S., Biosynthesis of ZnO nanoparticles through extract from Prosopis juliflora plant leaf: Antibacterial activities and a new approach by rust-induced photocatalysis, J. Saudi Chem. Soc., 24(5), pp. 393-406, 2020.

[11] Goswami, M., Adhikary, N. C., and Bhattacharjee, S., Effect of annealing temperatures on the structural and optical properties of zinc oxide nanoparticles prepared by chemical precipitation method, Optik (Stuttg)., 158(2010), pp. 1006-1015, 2018.

[12] Kabir, M. H., Ali, M. M., Kaiyum, M. A., and Rahman, M. S., Effect of annealing temperature on structural morphological and 
optical properties of spray pyrolized Aldoped $\mathrm{ZnO}$ thin films, J. Phys. Commun., 3(10), pp. 1-11, 2019.

[13] Vijay Kumar, P. P. N., Pammi, S. V. N., Kollu, P., Satyanarayana, K. V. V., and Shameem, U., Green synthesis and characterization of silver nanoparticles using Boerhaavia diffusa plant extract and their anti bacterial activity, Ind. Crops Prod., 52, pp. 562-566, 2014.

[14] Cahyono, Y., Muttaqin, F. D., Maslakah, U., Baqiya, M. A., Zainuri, M., Yahya, E., Pratapa, S., \& Darminto, D.,, Efek Staebler-Wronski dan Pengaruh Waktu Anil pada Lapisan Instrinsik Silikon Amorf Terhidrogenasi (a-Si:H), J. Fis. dan Apl., 13(2), pp. 59-62, 2017.

[15] Doan Thi, T. U., Nguyen, T. T., Thi, Y. D., Ta Thi, K. H., Phan, B. T., and Pham, K. N., Green synthesis of $\mathrm{ZnO}$ nanoparticles using orange fruit peel extract for antibacterial activities,
RSC Adv., 10(40), pp. 23899-23907, 2020.

[16] Mohammadi, C., Mahmud, S., Abdullah, S. M., and Mirzaei, Y., Green synthesis of ZnO nanoparticles using the aqueous extract of Euphorbia petiolata and study of its stability and antibacterial properties, Moroccan J. Chem., 5(3), pp. 476-484, 2017.

[17] Yadav, L. S. R. et al., Antibacterial and photocatalytic activities of $\mathrm{ZnO}$ nanoparticles: Synthesized using water melon juice as fuel, Int. J. Nanosci., 15(1), pp. 1-2, 2016.

[18] Matinise, N., Fuku, X. G., Kaviyarasu, K., Mayedwa, N., and Maaza, M., ZnO nanoparticles via Moringa oleifera green synthesis: Physical properties \& mechanism of formation, Appl. Surf. Sci., 406, pp. 339347, 2017. 